\title{
Thiomicrospira chilensis sp. nov., a mesophilic obligately chemolithoautotrophic sulfur- oxidizing bacterium isolated from a Thioploca mat
}

\author{
Thorsten Brinkhoff, ${ }^{1}$ Gerard Muyzer, ${ }^{3}$ Carl O. Wirsen ${ }^{4}$ and Jan Kuever ${ }^{2}$
}

Author for correspondence: Jan Kuever. Tel: +49 4212028 734. Fax: +49 4212028580.

e-mail: jkuever@mpi-bremen.de

\footnotetext{
1,2 Molecular Ecology Group ${ }^{1}$ and Department of Microbiology2, MaxPlanck-Institute for Marine Microbiology, Celsiusstraße 1, D-28359 Bremen, Germany

3 Netherlands Institute for Sea Research (NIOZ), PO Box 59, NI-1790 AB Den Burg (Texel), The Netherlands

4 Department of Biology, Woods Hole Oceanographic Institution, Woods Hole, MA 02543, USA
}

\begin{abstract}
A new member of the genus Thiomicrospira, which utilizes thiosulfate as the electron donor and $\mathrm{CO}_{2}$ as the carbon source, was isolated from a sediment sample dominated by the filamentous sulfur bacterium Thioploca. Although the physiological properties investigated are nearly identical to other described species of the genus, it is proposed that strain Ch-1 ${ }^{\top}$ is a member of a new species, Thiomicrospira chilensis sp. nov., on the basis of differences in genotypic characteristics (16S rRNA sequence, DNA homology, G+C content). Strain Ch-1' was highly motile with a slight tendency to form aggregates in the stationary growth phase. The organism was obligately autotrophic and strictly aerobic. Nitrate was not used as an electron acceptor. Chemolithoautotrophic growth was observed with thiosulfate, tetrathionate, sulfur and sulfide. The isolate was not able to grow heterotrophically. Growth of strain Ch-1' was observed between pH 5.3 and 8.5 with an optimum at pH 7.0. The temperature range for growth was between 3.5 and $42{ }^{\circ} \mathrm{C}$; the optimal growth temperature was between 32 and $37^{\circ} \mathrm{C}$. The mean maximum growth rate on thiosulfate was $0.4 \mathrm{~h}^{-1}$. This is the second Thiomicrospira species described that has a rodshaped morphology; therefore discrimination between vibrio-shaped Thiomicrospira and rod-shaped Thiobacilli is no longer valid.
\end{abstract}

Keywords: Thiomicrospira chilensis sp. nov., sulfur-oxidizing bacteria, Thioploca mat

\section{INTRODUCTION}

Most Thiomicrospira species described so far were isolated from deep-sea hydrothermal vents and intertidal mud flats (Kuenen \& Veldkamp, 1972; Ruby et al., 1981; Ruby \& Jannasch, 1982; Jannasch et al., 1985; Wood \& Kelly, 1989; Eberhard et al., 1995; Brinkhoff et al., 1999). All members of this genus are obligately chemolithoautotrophic sulfur-oxidizing bacteria. The ecological importance of Thiomicrospira species in marine habitats rich in reduced-sulfur compounds has already been demonstrated (Muyzer $e t$ al., 1995; Brinkhoff \& Muyzer, 1997) but very little is known about their role in sulfide-influenced habitats that have a mat-like community structure. In these habitats, they have to compete with other, very

\footnotetext{
Abbreviation: RuBisCO, ribulose-bisphosphate carboxylase/oxygenase. The GenBank accession number for the 165 rDNA sequence of strain $\mathrm{Ch}^{-1}{ }^{\mathrm{T}}$ reported in this paper is AF013975.
}

specialized bacteria for the electron donor, sulfide, or other reduced-sulfur compounds. In light-influenced mat systems they have to compete with phototrophic bacteria. Nevertheless, a Thiomicrospira species was isolated from a sediment sample from the Solar Lake, Egypt, which can be regarded as an model system for such an ecosystem (Brinkhoff \& Muyzer, 1997). In the work described in this paper, we used samples from a different mat-like community, the Thioploca mats on the Chilean coastal shelf, to obtain Thiomicrospira isolates.

\section{METHODS}

Culture media and isolation of bacteria. The medium used (TP) and the procedure for isolation were as described previously (Brinkhoff et al., 1999).

Growth experiments and utilization of electron donors. All growth experiments and tests for electron donors were carried out as described previously (Brinkhoff et al., 1999); the results are summarized in Table 3 . 
Chemical, biochemical and molecular-biological analysis. The formation of intermediates and final products during growth on thiosulfate was monitored by cyanolysis (Kelly et al., 1969) and HPLC (Rethmeier et al., 1997). The ubiquinones were analysed by B. J. Tindall (DSMZ Identification Service, Braunschweig, Germany) and the DNA base composition analysis and the DNA-DNA hybridizations were carried out by J. Burghardt (DSMZ), as described previously (Brinkhoff et al., 1999).

The ribulose-bisphosphate carboxylase/oxygenase (RuBisCO) activity in cell-free extracts was measured at $30^{\circ} \mathrm{C}$ as described before (Brinkhoff et al., 1999). The 16S rRNA sequence of strain $\mathrm{Ch}-1^{\mathrm{T}}$ and its phylogenetic position have been reported (Brinkhoff \& Muyzer, 1997). In this paper we show a similarity matrix of the $16 \mathrm{~S}$ rRNA sequences of all described Thiomicrospira species and closely related organisms.

\section{RESULTS}

\section{Isolation of strain $\mathrm{Ch}-1^{\top}$}

Enrichment cultures were inoculated with mud from the continental shelf off Chile at the Bay of Concepcion at $36^{\circ} 32^{\prime} \mathrm{S}$ (Fossing et al., 1995). Using sulfide gradients, we observed a large number of spirillum-like organisms containing mainly two sulfur globules and forming 'Bakterienplatten' located in the regions of optimal $\mathrm{H}_{2} \mathrm{~S}$ and $\mathrm{O}_{2}$ concentrations. These organism looked very similar to 'Thiospira bipunctata', which was first described by Molisch (1912). A more recent publication revised the taxonomic position of this taxon and described it as 'Aquaspirillum bipunctata' (Dubinina et al., 1993). After several attempts to enrich and isolate these organisms, a good enrichment culture was only obtained by using thiosulfate as the electron donor. Differing from the original enrichment on sulfide, this culture was dominated by short vibrios and rods without sulfur globules. Using solid modified medium TP, as described recently (Brinkhoff et al., 1999), a vibrio-shaped organism (Ch-2) was isolated. After filtration of the enrichment culture through a $0.45 \mu \mathrm{m}$ filter, a rod-shaped, sulfur-oxidizing bac-

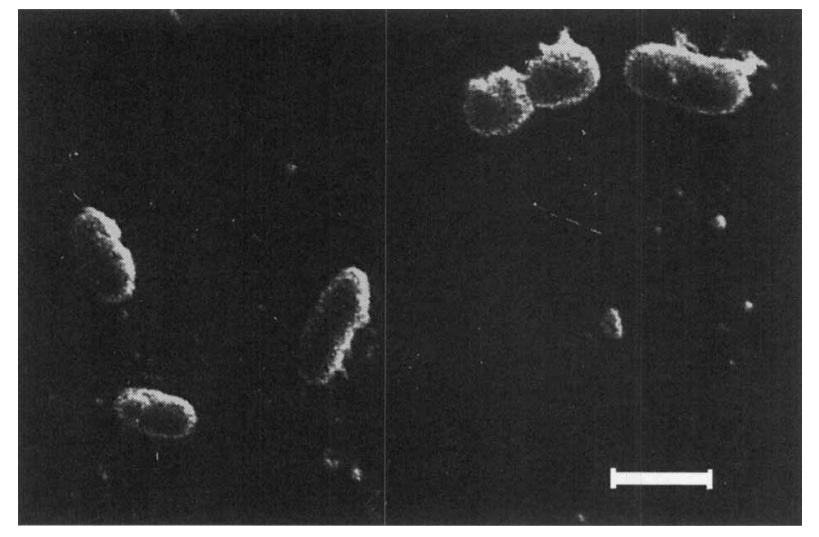

Fig. 1. Electron micrograph of strain $\mathrm{Ch}-1^{\top}$, showing the typical rod-shaped cell form. Bar, $1 \mu \mathrm{m}$.

terium $\left(\mathrm{Ch}-1^{\mathrm{T}}\right)$ was obtained in pure culture. Both isolates were identified as Thiomicrospira species by using the specific PCR approach (Brinkhoff \& Muyzer, 1997). The two isolates could be distinguished on the basis of nearly complete sequences of the 16S rRNAencoding genes. The sequence obtained from the vibrio-shaped Thiomicrospira isolate was nearly identical $(99.5 \%)$ to that of Thiomicrospira crunogena, whereas the sequence obtained from the rod-shaped isolate showed less than $96 \%$ identity to all Thiomicrospira species described (see Table 1). Therefore, only this latter isolate, known as Thiomicrospira sp. $\mathrm{Ch}-1^{\mathrm{T}}$, was characterized further.

\section{Morphology}

Cells of strain Ch- $1^{\mathrm{T}}$ appeared as single, motile rods of $0.3-0.5 \times 0.8-2 \mu \mathrm{m}$ (Fig. 1). In the late-exponential growth phase, cells of strain $\mathrm{Ch}-1^{\mathrm{T}}$ showed a tendency to clump, resulting in the formation of aggregates, as described previously for Thiomicrospira frisia (Brinkhoff et al., 1999). Spore formation was absent and the Gram reaction was negative.

Table 1. 165 rDNA identities between strain $\mathrm{Ch}-1^{\top}$ and related taxa of the $\gamma$-subclass of the Proteobacteria

Sequences with the following accession numbers were compared: Chromatium (Chr.) vinosum, M26629; Calyptogena (Cal.) magnifica gill symbiont, M99446; Thiomicrospira pelophila, L40809; Thiomicrospira thyasirae, AF016046; Thiomicrospira crunogena, L40810; Thiomicrospira sp. L-12, L01576; Thiomicrospira sp. MA2-6, L40811; Thiomicrospira kuenenii, AF013978; Thiomicrospira frisia, AF013974; Thiomicrospira chilensis strain Ch-1 ${ }^{\mathrm{T}}, \mathrm{AF} 013975$.

\begin{tabular}{|c|c|c|c|c|c|c|c|c|c|}
\hline Taxon & Chr. vinosum & $\begin{array}{c}\text { Cal. magnifica } \\
\text { gill symbiont }\end{array}$ & T. pelophila & T. thyasirae & T. crunogena & $\begin{array}{l}\text { Thiomicrospira } \\
\text { sp. L-12 }\end{array}$ & $\begin{array}{c}\text { Thiomicrospira } \\
\text { sp. MA2-6 }\end{array}$ & T. kuenenii & T. frisia \\
\hline \multicolumn{10}{|l|}{ Chromatium vinostum } \\
\hline Calyptogena magnifica gill symbiont & $84 \cdot 0$ & & & & & & & & \\
\hline Thiomicrospira pelophila & $85 \cdot 0$ & $84 \cdot 7$ & & & & & & & \\
\hline Thiomicrospira thyasirae & $85 \cdot 6$ & $85 \cdot 1$ & $99 \cdot 9$ & & & & & & \\
\hline Thiomicrospira crunogena & $84 \cdot 9$ & $84 \cdot 2$ & $92 \cdot 5$ & $92 \cdot 5$ & & & & & \\
\hline Thiomicrospira sp. L-12 & $86 \cdot 0$ & $84 \cdot 6$ & $92 \cdot 4$ & 92.4 & $99 \cdot 2$ & & & & \\
\hline Thiomicrospira sp. MA2-6 & $84 \cdot 9$ & $84 \cdot 7$ & $92 \cdot 6$ & $92 \cdot 7$ & $97 \cdot 3$ & $97 \cdot 4$ & & & \\
\hline Thiomicrospira kuenenii & $84 \cdot 1$ & $83 \cdot 1$ & $94 \cdot 1$ & $92 \cdot 3$ & $95 \cdot 7$ & $96 \cdot 1$ & $95 \cdot 1$ & & \\
\hline Thiomicrospira frisia & $84 \cdot 1$ & $84 \cdot 0$ & $91 \cdot 1$ & $91 \cdot 3$ & $94 \cdot 7$ & $94 \cdot 8$ & $93 \cdot 5$ & $92 \cdot 2$ & \\
\hline Thiomicrospira chilensis $\mathrm{Ch}-1^{\mathrm{T}}$ & $83 \cdot 8$ & $84 \cdot 8$ & $92 \cdot 1$ & $92 \cdot 3$ & $94 \cdot 9$ & $94 \cdot 9$ & 93.9 & $93 \cdot 1$ & $95 \cdot 3$ \\
\hline
\end{tabular}


Table 2. Levels of DNA-DNA similarity for Thiomicrospira species

\begin{tabular}{|c|c|c|c|c|}
\hline \multirow[t]{2}{*}{ Taxon } & \multicolumn{4}{|c|}{ Relatedness (\%) } \\
\hline & T. pelophila & T. crunogena & T. kuenenii JB-A1 ${ }^{\mathrm{T}}$ & T. frisia $\mathbf{~ J B}-\mathbf{A 2}^{\mathrm{T}}$ \\
\hline T. pelophila & 100 & & & \\
\hline T. crunogena & $33 \cdot 5$ & 100 & & \\
\hline T. kuenenii JB-A $1^{\mathrm{T}}$ & 25 & $29 \cdot 3$ & 100 & \\
\hline T. frisia JB-A2 ${ }^{\mathrm{T}}$ & 27 & 27 & 25 & \\
\hline T. chilensis Ch- $\mathrm{1}^{\mathrm{T}}$ & 31 & 27 & 16 & 18 \\
\hline
\end{tabular}

\section{Growth conditions}

The isolate was strictly aerobic and grew autotrophically on thiosulfate, tetrathionate, sulfur and sulfide but not on sulfite or thiocyanate. Growth on thiosulfate reduced the $\mathrm{pH}$ from $7 \cdot 2$ to $4 \cdot 5$. Thiosulfate was completely oxidized to sulfate, with a recovery of 92-99\%. Intermediate formation of elemental sulfur was observed on solid media and in liquid media. No growth occurred in TP medium supplemented with any of the organic substrates tested. The oxidation of thiosulfate was not inhibited by any of the organic substrates. Nitrate $(10 \mathrm{mM})$ was not used as a terminal electron acceptor; nitrite was not tested. Hydrogen was not used as an electron donor for autotrophic growth. Addition of vitamin $B_{12}$ enhanced growth but was not essential for growth. For strain Ch- $1^{\mathrm{T}}$, growth was observed between $\mathrm{pH} 5.3$ and 8.5 with an optimum at $\mathrm{pH} 7 \cdot 0$. At $30^{\circ} \mathrm{C}$ and optimal $\mathrm{pH}$, the maximum growth rate on thiosulfate was $0 \cdot 4 \mathrm{~h}^{-1}$.

When the $\mathrm{pH}$ was readjusted to the optimal $\mathrm{pH}$ during growth on thiosulfate, the new isolate caused a strong sulfur precipitation only at the beginning of the growth phase, similar to $T$. crunogena. The only intermediate found was sulfite, at a concentration varying from $0 \cdot 1$ to $2 \cdot 1 \mathrm{mM}$. Tetrathionate was not detected.

\section{RuBisCO activity}

$\mathrm{RuBisCO}$ activity was found in cell-free extracts of the new isolate. The specific activity for strain $\mathrm{Ch}-1^{\mathrm{T}}$ was $8.2 \mathrm{nmol}$ carbon fixed $\mathrm{mg}$ protein ${ }^{-1} \mathrm{~min}^{-1}$.

\section{DNA base ratio and ubiquinone content}

The $\mathrm{G}+\mathrm{C}$ content of DNA of strain $\mathrm{Ch}-1^{\mathrm{T}}$ was $49.9 \pm 0.2 \mathrm{~mol} \%$. The isolate contained Q-8 as the major ubiquinone and small traces of ubiquinone Q-7.

\section{Phylogenetic analysis and DNA-DNA hybridization}

A 16S rRNA sequence similarity matrix and the results of the DNA-DNA hybridizations are shown in Tables 1 and 2 . These results show clearly that strain $\mathrm{Ch}-1^{\mathrm{T}}$ can be considered as a new Thiomicrospira species.

\section{DISCUSSION}

Thioploca species are well adapted to use nitrate as a terminal electron acceptor. All Thiomicrospira species, with the exception of Thiomicrospira denitrificans, are dependent on oxygen as the terminal electron acceptor. Although still included within the genus, $T$. denitrifcans should be reclassified because it belongs to the $\varepsilon$ subclass of the Proteobacteria (Muyzer et al., 1995). Using DNA extracted from these Thioploca mats, the specific PCR approach was negative for Thiomicrospira species belonging to the $\gamma$-subclass of the Proteobacteria (Brinkhoff \& Muyzer, 1997), suggesting that the numbers of individuals from this genus are negligible in this habitat compared with hydrothermal vent systems. Nevertheless, we were able to isolate two Thiomicrospira species from this sampling site, which was dominated by filamentous, sulfur-oxidizing bacteria. The additional finding of another isolate of $T$. crunogena supports the thesis of Wirsen et al. (1998) that this species can be found worldwide and seems to be favoured by using enrichment techniques.

Comparison of the nearly complete 16S rRNA-gene sequence shows that the sequence of strain $\mathrm{Ch}-1^{\mathrm{T}}$ is at least $4 \%$ different from other Thiomicrospira species that have been described. According to the definition of Stackebrandt \& Goebel (1994), this indicates that strain $\mathrm{Ch}-1^{\mathrm{T}}$ does not belong to a species already described. The level of DNA-DNA hybridization shown in Table 2 is far below the critical value of $70 \%$ (Wayne et al., 1987). In addition, as Table 3 shows, there are also some physiological differences between the new isolate and other species described previously. The DNA base ratio of $49.9 \%$ for strain $\mathrm{Ch}-1^{\mathrm{T}}$ is much higher than those for the other species of the genus. Based on the great genotypic differences, it can be speculated that strain $\mathrm{Ch}-1^{\mathrm{T}}$ may also have some metabolic properties that separate it from other Thiomicrospira species, but which were not detected using the general descriptive methods. Like $T$. frisia, strain $\mathrm{Ch}-1^{\mathrm{T}}$ has a rod-like shape, which is not found for the other Thiomicrospira species. Differentiation of Thiomicrospira species from Thiobacillus species on the basis of morphology is no longer valid. Together with T. frisia and Thiomicrospira sp. strain Art-3, strain Ch$1^{\mathbf{T}}$ falls into a sub-cluster of rod-shaped organisms ( $\mathrm{J}$. Kuever, unpublished results) within the Thiomicro- 
Table 3. Morphological and physiological characteristics among Thiomicrospira species

Data were obtained from the present study and from Kuenen \& Veldkamp (1972, 1973), Kuenen \& Robertson (1989), Jannasch et al. (1985) and Brinkhoff et al. (1999).

\begin{tabular}{|c|c|c|c|c|c|}
\hline Character & T. pelophila & T. crunogena & $\begin{array}{l}\text { T. kuenenii } \\
\text { JB-A1 }^{\mathrm{T}}\end{array}$ & $\begin{array}{l}\text { T. frisia } \\
\text { JB-A2 }\end{array}$ & $\begin{array}{l}\text { T. chilensis } \\
\text { Ch-1 }^{\mathrm{T}}\end{array}$ \\
\hline Shape & Vibrio & Vibrio & Vibrio & Rod & Rod \\
\hline Width $(\mu \mathrm{m})$ & $0 \cdot 2-0 \cdot 3$ & $0.4-0.5$ & $0 \cdot 3-0 \cdot 4$ & $0 \cdot 3-0.5$ & $0 \cdot 3-0.5$ \\
\hline Length $(\mu \mathrm{m})$ & $1-2$ & $1 \cdot 5-3.0$ & $1-2 \cdot 5$ & $1-2 \cdot 7$ & $0 \cdot 8-2$ \\
\hline Motility & + & + & + & $+^{*}$ & + \\
\hline $\mathrm{G}+\mathrm{C}$ content $(\mathrm{mol} \%) \dagger$ & $45 \cdot 7(44)$ & $44 \cdot 2(42)$ & $42 \cdot 4$ & $39 \cdot 6$ & $49 \cdot 9$ \\
\hline Ubiquinone & Q-8 & Q-8 & Q-8 & Q-8 & Q-8 \\
\hline Maximum growth rate $\left(\mathrm{h}^{-1}\right)$ & $0 \cdot 3$ & 0.8 & $0 \cdot 35$ & 0.45 & $0 \cdot 4$ \\
\hline \multicolumn{6}{|l|}{ Growth $\mathrm{pH}$ : } \\
\hline Optimal & $7 \cdot 0 \ddagger$ & $7 \cdot 5-8 \cdot 0$ & $6 \cdot 0$ & 6.5 & $7 \cdot 0$ \\
\hline Range & $5 \cdot 6-9 \cdot 0$ & $5 \cdot 0-8 \cdot 5$ & $4 \cdot 0-7 \cdot 5$ & $4 \cdot 2-8 \cdot 5$ & $5 \cdot 3-8 \cdot 5$ \\
\hline \multicolumn{6}{|l|}{ Growth temperature $\left({ }^{\circ} \mathrm{C}\right)$ : } \\
\hline Optimal & $28-30$ & $28-32$ & $29-33 \cdot 5$ & $32-35$ & $32-37$ \\
\hline Range§ & $3 \cdot 5-42$ & $4-38 \cdot 5$ & $3 \cdot 5-42$ & $3 \cdot 5-39$ & $3 \cdot 5-42$ \\
\hline \multicolumn{6}{|l|}{$\mathrm{Na}^{+}$concentration $(\mathrm{mM}):$} \\
\hline Optimal & 470 & ND & 470 & 470 & 470 \\
\hline Range & $40-1240 \|$ & $>45$ & $100-640$ & $100-1240$ & $100-1240$ \\
\hline Vitamin $B_{12}$ dependence & + & - & - & - & - \\
\hline RuBisCO activity & + & + & + & + & + \\
\hline $\begin{array}{l}\text { Formation of sulfur from thiosulfate } \\
\text { at } \mathrm{pH} 7.0 \text { in liquid medium }\end{array}$ & + & + & - & - & + \\
\hline
\end{tabular}

* Motility can decrease rapidly during growth.

† Determined by HPLC; values in parentheses were determined previously by thermal denaturation.

$\ddagger$ Data from present study, determined by $\mathrm{CO}_{2}$ incorporation.

$\S$ Growth of all taxa except $T$. crunogena would be likely to occur below $3.5^{\circ} \mathrm{C}$.

$\|$ In medium without $\mathrm{NaCl}$ there was at least $20 \mathrm{mM} \mathrm{Na} \mathrm{S}_{2} \mathrm{O}_{3}$ present; cells of $T$. pelophila showed pleomorphism at low $\mathrm{Na}^{+}$ concentrations.

spira cluster, which was notable in the phylogenetic tree published by Brinkhoff \& Muyzer (1997). Therefore, we propose that the isolate $\mathrm{Ch}-1^{\mathrm{T}}$ should be considered as a new species of this genus and be given the name Thiomicrospira chilensis $\mathrm{sp}$. nov.

Thiomicrospira chilensis (chi.len'sis. M.L. adj. chilensis from Chile, South America).

Cells are Gram-negative, motile and rod-shaped $(0 \cdot 3-$ $0.5 \times 0.8-2 \mu \mathrm{m})$. Strictly aerobic and grows autotrophically on thiosulfate, tetrathionate, sulfur and sulfide but not on sulfite or thiocyanate. Does not grow heterotrophically. When thiosulfate is used as the primary energy source, sulfur and very small amounts of sulfite are produced. During growth on reducedsulfur compounds, the $\mathrm{pH}$ decreases from neutrality to around $4 \cdot 8$. Thiosulfate is completely oxidized to sulfate. Autotrophic growth on thiosulfate occurs between $\mathrm{pH} 5.3$ and 8.5 and at a temperature of $3.5-42{ }^{\circ} \mathrm{C}$; optimal growth occurs at $\mathrm{pH} 7.0$ and at $32-37^{\circ} \mathrm{C}$. The optimal $\mathrm{Na}^{+}$concentration for growth is $470 \mathrm{mM}$; growth is possible between $\mathrm{Na}^{+}$concen- trations of 100 and $1240 \mathrm{mM}$. Carbon dioxide is fixed by means of ribulose-bisphosphate carboxylase/ oxygenase. Nitrate is not used as a terminal electron acceptor. On thiosulfate agar, cells produce white to yellowish, smooth, entire colonies [diameter on $1.2 \%$ $(\mathrm{w} / \mathrm{v})$ agar is $2-5 \mathrm{~mm}$ ] in which sulfur is deposited and acid is produced. Ubiquinone Q- 8 is present in the respiratory chain. The $\mathrm{G}+\mathrm{C}$ content of the DNA is $49.9 \mathrm{~mol} \%$. As determined by a $16 \mathrm{~S}$ rRNA gene sequence analysis, Thiomicrospira chilensis belongs to the $\gamma$-subclass of the Proteobacteria and is closely related to previously described members of the genus Thiomicrospira. The type strain of the species, Ch- ${ }^{\mathrm{T}}$, has been deposited at the Deutsche Sammlung von Mikroorganismen und Zellkulturen as strain DSM $12352^{\mathrm{T}}$. The GenBank accession number for the nearly complete $16 \mathrm{~S}$ rRNA gene sequence of $T$. chilensis is AF013975.

The authors thank B. Braun, T. Heidorn, H. W. Jannasch (deceased), J. G. Kuenen, I. Kunze, J. Lüchtenborg, V. Meyer, J. Rethmeier, H. Schulz, H. Stevens, A. Teske and H. 
G. Trüper for advice and help. The project was supported by the Max-Planck-Society and also in part by the National Science Foundation grant OCE-9615830 awarded to C.O.W. This is contribution no. 9773 from the Woods Hole Oceanographic Institution.

\section{REFERENCES}

Brinkhoff, T. \& Muyzer, G. (1997). Increased species diversity and extended habitat range of sulfur-oxidizing Thiomicrospira spp. Appl Environ Microbiol 63, 3789-3796.

Brinkhoff, T., Muyzer, G., Wirsen, C. O. \& Kuever, J. (1999). Thiomicrospira kuenenii sp. nov. and Thiomicrospira frisia $\mathrm{sp}$. nov., two mesophilic obligately chemolithotrophic sulfuroxidizing bacteria isolated from an intertidal mud flat. Int J Syst Bacteriol 49, 385-392.

Dubinina, G. A., Grabovich, M. Y., Lysenko, A. M., Chernykh, N. A. \& Churikova, V.V. (1993). Revision of the taxonomic position of colorless sulfur spirilla of the genus Thiospira and description of a new species, Aquaspirillum bipunctata comb. nov. Microbiology 62, 638-644 (English translation of Mikrobiologiya).

Eberhard, C., Wirsen, C. O. \& Jannasch, H. W. (1995). Oxidation of polymetal sulfides by chemolithoautotrophic bacteria from deep-sea hydrothermal vents. Geomicrobiol J 13, 145-164.

Fossing, H., Gallardo, V. A., Jørgensen, B. B. \& 12 other authors (1995). Concentration and transport of nitrate by the matforming sulphur bacterium Thioploca. Nature 374, 713-715.

Jannasch, H. W., Wirsen, C. O., Nelson, D. C. \& Robertson, L. A. (1985). Thiomicrospira crunogena sp. nov., a colorless, sulfuroxidizing bacterium from a deep-sea hydrothermal vent. Int $J$ Syst Bacteriol 35, 422-424.

Kelly, D. P., Chambers, L. A. \& Trudinger, P. A. (1969). Cyanolysis spectrophotometric estimation of trithionate in mixture with thiosulfate and tetrathionate. Anal Chem 41, 898-901.

Kuenen, J. G. \& Robertson, L. A. (1989). Genus Thiomicrospira Kuenen and Veldkamp. In Bergey's Manual of Systematic Bacteriology, vol. 3, pp. 1858-1861. Edited by J. T. Staley, M. P. Bryant, N. Pfennig \& J. G. Holt. Baltimore: Williams \& Wilkins.
Kuenen, J. G. \& Veldkamp, H. (1972). Thiomicrospira pelophila, gen. n., sp. n., a new obligately chemolithotrophic colourless sulfur bacterium. Antonie Leeuwenhoek 38, 241-256.

Kuenen, J. G. \& Veldkamp, H. (1973). Effects of organic compounds on growth of chemostat cultures of Thiomicrospira pelophila, Thiobacillus thioparus and Thiobacillus neapolitanus. Arch Mikrobiol 94, 173-190.

Molisch, H. (1912). Neue farblose Schwefelbakterien. Zentralbl Bakteriol Parasitenkd Infektionskr Hyg Abt 2 33, 55-62.

Muyzer, G., Teske, A., Wirsen, C. O. \& Jannasch, H. W. (1995). Phylogenetic relationships of Thiomicrospira species and their identification in deep-sea hydrothermal vent samples by denaturing gradient gel electrophoresis of $16 \mathrm{~S}$ rDNA fragments. Arch Microbiol 164, 165-172.

Rethmeier, J., Rabenstein, A., Langer, M. \& Fischer, U. (1997). Detection of traces of oxidized and reduced sulfur compounds in small samples by combination of different high-performance liquid chromatography methods. J Chromatogr A 760, 295-302.

Ruby, E. G. \& Jannasch, H. W. (1982). Physiological characteristics of Thiomicrospira sp. strain L-12 isolated from deep-sea hydrothermal vents. $J$ Bacteriol 149, 161-165.

Ruby, E. G., Wirsen, C. O. \& Jannasch, H. W. (1981). Chemolithoautotrophic sulfur-oxidizing bacteria from the Galapagos Rift hydrothermal vents. Appl Environ Microbiol 42, 317-342.

Stackebrandt, E. \& Goebel, B. M. (1994). Taxonomic note: a place for DNA-DNA reassociation and 16S rRNA sequence analysis in the present species definition in bacteriology. Int $J$ Syst Bacteriol 44, 846-849.

Wayne, L. G., Brenner, D. J., Colwell, R. R. \& 9 other authors (1987). International Committee on Systematic Bacteriology. Report of the ad hoc committee on reconciliation of approaches to bacterial systematics. Int J Syst Bacteriol 37, 463-464.

Wirsen, C. O., Brinkhoff, T., Kuever, J., Muyzer, G., Molyneaux, S. \& Jannasch, H. W. (1998). Comparison of a new Thiomicrospira strain from the Mid-Atlantic Ridge with known hydrothermal vent isolates. Appl Environ Microbiol 64, 4057-4059.

Wood, A. P. \& Kelly, D. P. (1989). Isolation and characterization of Thiobacillus thyasiris sp. nov., a novel marine facultative autotroph and the putative symbiont of Thyasira flexuosa. Arch Microbiol 152, 160-166. 